\title{
Analisis Nitrat dan Fosfat Terhadap Sebaran Fitoplankton Sebagai Bioindikator Kesuburan Perairan Muara Sungai Bodri
}

\author{
Imam Mishbach ${ }^{1 *}$, Muhammad Zainuri² ${ }^{2}$ Widianingsih $^{1}$, Hermin Pancasakti \\ Kusumaningrum $^{3}$, Denny Nugroho Sugianto ${ }^{2}$, Rudhi Pribadi ${ }^{1}$ \\ ${ }^{1}$ Departemen Ilmu Kelautan, Fakultas Perikanan dan Ilmu Kelautan, Universitas Diponegoro \\ ${ }^{2}$ Departemen Oseanografi, Fakultas Perikanan dan Ilmu Kelautan, Universitas Diponegoro \\ ${ }^{3}$ Departemen Biologi Fakultas Sains dan Matematika, Universitas Diponegoro \\ Jl. Prof. H. Soedarto S.H, Tembalang, Semarang, Jawa Tengah 50275 Indonesia \\ Email: imammishbach71@gmail.com
}

\begin{abstract}
Abstrak
Nitrat dan fosfat adalah unsur nutrien yang menjadi pembatas kelimpahan fitoplankton. Kandungan nitrat dan fosfat di perairan muara akan dipengaruhi oleh faktor biologi, fisika dan kimia perairan, yang menyebabkan timbulnya suatu persebaran. Hal tersebut menjadi permasalahan di Muara Sungai Bodri, Kendal. Tujuan dari penelitian ini adalah untuk mengkaji kandungan nitrat dan fosfat beserta pola persebarannya, serta keterkaitannya dengan struktur populasi fitoplankton sebagai bioindikator kesuburan perairan di Perairan Muara Sungai Bodri, Kabupaten Kendal. Penelitian dilaksanakan berdasarkan metoda observasi dengan pendekatan spatio-temporal. Sejumlah 9 stasiun penelitian dan 3 kali waktu sampling yaitu 30 Juni, 1 September dan 27 Oktober 2018. Kandungan nitrat dan fosfat serta kelimpahan fitoplankton ditetapkan sebagai variabel terikat. Sedangkan parameter fisika dan kimia perairan seperti suhu, salinitas, derajat keasaman ( $\mathrm{pH})$, oksigen terlarut, kecerahan dan arus ditetapkan sebagai variabel kontrol. Hasil penelitian menunjukan bahwa kandungan nitrat berkisar 0,49-0,9 mg/l serta kandungan fosfat berkisar 0,01-0,29 mg/l yang menunjukkan bahwa perairan Muara Sungai Bodri, Kabupaten Kendal dalam kondisi subur/eutrofik. Kelimpahan fitoplankton menunjukkan nilai kisaran diantara 2.356 sampai dengan $162.626 \mathrm{sel} / \mathrm{l}$, yang tersusun oleh 5 kelas dan 45 jenis/species dengan pola persebaran berbentuk konvergen yang bertumpu pada stasiun 3 dan 5 . Perairan Muara Sungai Bodri, Kabupaten Kendal menunjukkan tingkat kesuburan yang tinggi atau eutrofik.
\end{abstract}

Kata kunci : Nitrat, Fosfat, Fitoplankton, Sebaran, Muara Sungai Bodri, Kendal

\section{Abstract}

\section{The Analysis of Nitrate and Phosphate to the Phytoplankton Distribution as The Bioindicator of Water Fertility at Bodri Estuary}

Nitrate and Phosphate are the nutrient element which influence as limiting factor to the phytoplankton population. Nitrate and Phosphate in the water were influence by physical and chemical factors, and will affect to the distribution. The distribution of nitrate and phosphate will affect the distribution of phytoplankton population. The purpose of the research is to analyze the distribution of phytoplankton population due to the influence of nitrate and phosphate contents at Bodri Estuary, Kendal. The research was apllied based on the spatio-temporel approach. There are 9 stations and triple sampling of 30 June, 1st Septembre and 27 Octobre, 2018. The nitrate and phosphate contents and phytoplankton abundance was set as dependent variables. The parameters temperature, salinity, $\mathrm{pH}$, Dissolved Oxygen, transparency and current were used as variable control. The research result show the nitrate content range between 0,49-0,9 mgr./l and the phosphate content range between 0,01-0,29 mgr./l, which indicate that the Bodri Estuary, Kendal is eutrophic. The distribution of nitrate and phosphate contens show a model of convergen on west area of sampling and tend to along the coastline in the east part. The phytoplankton abundance show a range of $2.356-162.626 \mathrm{cell} / \mathrm{l}$, which composed of 5 Class and 45 species.

Keywords : Nitrate, Phosphate, Phytoplankton, Distribution, Bodri Estuary, Kendal 


\section{PENDAHULUAN}

Wilayah pesisir di Pantai Utara Pulau Jawa terdiri dari pantai, muara sungai, dan estuaria yang dapat diklasifikasikan sebagai perairan (Diposaptono, et al. 2009 dan Diposaptono; 2015). Wilayah pesisir ke arah darat meliputi bagian daratan, baik kering maupun terendam air, yang masih dipengaruhi sifat-sifat laut seperti pasang surut, angin laut dan perembesan air asin. Sedangkan ke arah laut, wilayah pesisir mencakup bagian laut yang masih dipengaruhi oleh prosesproses alami yang terjadi di darat seperti sedimentasi, aliran air tawar, dan pengaruh yang disebabkan oleh kegiatan manusia di darat seperti penggundulan hutan dan pencemaran. Wilayah pesisir berdasarkan garis pantai (coastline) memiliki dua macam batas (boundaries), yaitu batas yang sejajar garis pantai (longshore) dan batas yang tegak lurus terhadap garis pantai (crossshore). Kondisi muara di wilayah pesisir dicirikan dengan suatu wilayah dimana terjadi pertemuan dua massa air dari daratan dan lautan dimana dipengaruhi oleh karakteristik fisika seperti pasang surut, arus sepanjang pantai, angin dan geomorfologi pantai dan kimia perairan seperti salinitas, $\mathrm{pH}$, fosfat dan nitrat (Widada, 2015). Kondisi tersebut menyebabkan daerah muara merupakan daerah yang selalu mengalami pertukaran, serta mengalami dinamika yang cukup tinggi (Gemilang, et al. 2018). Kompleksitas dan dinamika perairan tersebut terkait erat dengan siklus biogeokimia diantara ekosistem daratan dan perairan (Erickson III et al. 2015).

Muara sungai merupakan daerah pertemuan massa air tawar dari darat dan laut (Soegiarto , 1976 ; Zainuri, 2010, Tuwo, 2011), yg merupakan salah satu contoh daerah estuari . Estuaria merupakan suatu wilayah ekologi sebagai tempat hidup berbagai organisme yang beradaptasi terhadap air payau. Perairan estuaria tersusun atas beberapa ekosistem, yang berfungsi dan memiliki daya dukung sebagai penjebak serta penyaring massa air dari daratan, serta menjadi tempat asuhan bagi beberapa biota seperti burung, ikan dan biota yang lain.

Muara Sungai sebagai wilayah ekosistem estuaria berperanan dalam siklus bahan kimia sebagai agen transfer, penyimpanan dan proses berlanjut. Keberadaan bahan organik di muara perairan akan terkait dengan ketersediaan zat hara yang merupakan salah satu unsur pembatas kualitas perairan (Sastrawijaya, 2009). Bahan organik akan menjadi salah satu sumber nitrogen dan fosfor, dimana merupakan bahan kimia yang sangat berpengaruh dalam kehidupan biota laut. Keberadaan nitrogen dan fosfor di dalam sistem perairan ada dalam berbagai bentuk, namun hanya beberapa saja yang dapat dimanfaatkan oleh alga dan tumbuhan air. Unsur nitrogen yang dapat dimanfaatkan adalah nitrit dan nitrat, sementara untuk fosfor berupa senyawa orto fosfat (Jones-Lee $\&$ Lee, 2005). Nitrat terbentuk memalui proses nitrifikasi, yaitu proses oksidasi ammonia menjadi nitrit dan nitrat dalam siklus nitrogen yang berlangsung pada kondisi aerob (Falkowski, 2003. Erickson III, et al., 2015 ; Maslukah, et al., 2019). Unsur nitrogen dan fosfor ini memiliki peran penting pada pertumbuhan fitoplankton atau mikro alga (Fachrul et al., 2005). Molekul fosfat dan nitrat akan dimanfaatkan oleh fitoplankton dalam proses kemo-autotrofi dan foto-autotrofi dalam proses fotosintesa, sehingga dapat menghasilkan oksigen dan karbohidrat (Falkowski, 2003).

Muara Sungai Bodri adalah salah satu bagian hilir Daerah Aliran Sungai (DAS) besar yang terletak di Kabupaten Kendal. Secara administrasi Daerah Aliran Sungai (DAS) Bodri berada di Provinsi Jawa Tengah yang terbagi atas 4 Kabupaten yaitu Kabupaten Wonosobo dan Kabupaten Temanggung di kawasan hulu, Kabupaten Kendal di kawasan hulu sekaligus hilir, dan Kabupaten Semarang. Aliran sungai ini membawa material sedimen dan limbah yang berasal dari hulu dan sepanjang daerah aliran sungai yang akan diendapkan di muara Sungai Bodri. Sedimen serta limbah yang masuk kedalam badan air Sungai Bodri merupakan hasil dari penggunaan tata lahan di wilayah dulu sebagai kawasan pariwisata, pemukiman, industri dan konversi lahan pegunungan menjadi kegiatan manusia serta pembangunan yang lain (Portal Resmi Kabupaten Kendal, 2020). Kegiatan konversi lahan tidak hanya terjadi di daerah hulu, namun juga terjadi di wilayah pesisir, seperti Industri UMK, dan yang terbesar adalah kawasan ekonomi khusus Kendal, dimana hampir sebagian besar lahan wilayah pesisir dikonversi menjadi pembangunan kawasan industri terpadu. Selanjutnya pembangunan Tol berbasis Tanggul Laut juga telah mulai dikerjakan, sehingga akan berdampak pula terhadap Ekosistem dan kondisi lingkungan di Muara Sungai Bodri.

Muara Sungai Bodri merupakan tempat terakumulasinya sedimen dan limbah dari daratan. Sebagian dari material ini akan disebarkan atau didistibusikan oleh arus ke arah laut lepas. Limbah 
organik dan bahan berbahaya akan terbawa arus, dimana sebagian akan mengendap di dasar perairan, serta sebagian yang lain terbawa ke muara. Proses degradasi bahan organik dan limbah yang terjadi di Muara Sungai Bodri untuk menjadi unsur kimia nutritif relatif kecil. Hasil penelitian Agustiningsih (2012) menunjukkan bahwa total fosfat sebagai $\mathrm{P}$ berada pada kisaran $0.0772-0.08$ $\mathrm{mg} / \mathrm{l}$, NO3-N antara $0.1756-0.1875 \mathrm{mg} / \mathrm{l}$ dan NO2-N berkisar $0.004-0.192 \mathrm{mg} / \mathrm{l}$. Lebih lanjut ditambahkan bahwa Beban Pencemaran untuk TSS sebesar 2.986,68 kg/hari, dan secara berturut-turut untuk NO3-N, NO2-N, dan PO4-P adalah 41,91 $\mathrm{kg} / \mathrm{hari}, 3,05 \mathrm{~kg} / \mathrm{hari}$ dan $17,87 \mathrm{~kg} / \mathrm{hari}$.

Penelitian struktur komunitas fitoplankton di Muara Sungai Bodri telah dilakukan untuk mengetahui spesies yang tekandung di dalamnya (Ramanda et al., 2018). Penelitian ini mencoba membahas kandungan nitrat dan fosfat hubungannya dengan sebaran fitoplankton di Muara Sungai Bodri, Kendal. Hasil penelitian ini diharapkan dapat memberikan informasi kandungan unsur hara (nitrat dan fosfat) beserta pola persebarannya, serta keterkaitannya dengan struktur populasi fitoplankton sebagai bioindikator kesuburan perairan di Perairan Muara Sungai Bodri, Kabupaten Kendal.

\section{MATERI DAN METODE}

Materi yang digunakan dalam penelitian ini meliputi data primer dan sekunder. Data primer antara lain nitrat, fosfat dan kelimpahan fitoplankton. Sedangkan data sekunder meliputi parameter kualitas air, arus, dan pasang surut. Penelitian ini dilakukan di perairan Muara Sungai Bodri, Kabupaten Kendal. Pengambilan sampel air dilakukan di 9 Stasiun dengan dilakukan ulangan masing-masing 3 kali setiap stasiun. Lokasi penelitian stasiun 1,2,3 terletak 100 meter dari Muara Sungai Bodri, stasiun 4,5,6 terletak 200 meter dari Muara Sungai Bodri, dan tasiun 7,8,9 terletak 300 meter dari Muara Sungai Bodri. Posisi stasiun ditentukan dengan GPS dengan metode purposive sampling. Pengambilan data dilakukan Juni-Oktober 2018 dengan pertimbangan musim timur (Juni-Agustus) dan musim peralihan II (September-November) serta pendekatan spasio temporal berdasarkan perubahan iklim.

Pengambilan sampel fitoplankton dilakukan secara akif dengan cara menarik plankton net secara horizontal yang ditarik oleh perahu dengan kecepatan 2 knot dan lama penarikan sampel selama 5 menit pada setiap titik. Hasil sampel yang diperoleh dimasukkan ke dalam botol sampel 500 $\mathrm{ml}$ dengan diberikan formalin $4 \%$ sebanyak $1 / 10$ bagian volume untuk diawetkan. Kemudian dilakukan identifikasi fitoplankton dengan menggunakan sedwigh rafter. Pengamatan menggunakan mikroskop binokuler dengan perbesaran 10 x 10 sebanyak 3 kali pengulangan. Identifikasi fitoplankton menggunakan buku identifikasi yamaji (1979). Pengukuran nitrat dan fosfat, diambil dari permukaan perairan dengan menggunakan botol Niskin, kemudian sampel tersebut dimasukkan ke botol sampel Poly-etilen $1000 \mathrm{ml}$ simpan kotak pendingin (coolbox) yang diberi es yang bertujuan agar sampel tidak rusak untuk kemudian dilakukan analisis di laboratorium. Pengambilan data parameter kualitas perairan dilakukan masing-masing 3 kali pengulangan meliputi $\mathrm{pH}$, suhu, dan salinitas diukur menggunakan Water Quality Checker, DO di ukur dengan DO meter, kecerahan diukur menggunakan sechi disk, arus diukur menggunakan Current Meter.

\section{Analisis Fitoplankton}

Kelimpahan fitoplankton dalam satu liter dapat dihitung dengan menggunakan rumus Welch (1952). Indeks keanekaragaman jenis biota dapat dihitung menggunakan indeks keanekaragaman Shanon - Wiener (Odum, 1994). Kriteria keanekaragaman dan pengklasifikasian tingkat pencemaran sungai berdasarkan (H') kriteria Indeks Shannon-Wiener (Odum, 1994), sebagai berikut: $\mathrm{H}^{\prime}<1=$ Keanekaragaman rendah; $<\mathrm{H}^{\prime}<3=$ Keanekaragaman sedang; H'>3= Keanekaragaman tinggi

Indeks keseragaman masing masing biota yang terdapat pada setiap stasiun dapat dihitung dengan menggunakan indeks keseragaman Odum (1994) Besarnya nilai E berkisar antara 0-1 (Odum (1994). Kriteria yang digunakan : $\mathrm{E}<0,4=$ Keseragaman rendah; $0,4 \leq \mathrm{E} \leq 0,6=$ Keseragaman sedang; E $>0,6=$ Keseragaman tinggi

Indeks Dominansi jenis fitoplankton di Perairan Muara Sungai Bodri, dapat dihitung menggunakan rumus Barus (2004). Kriteria Indeks dominasi menurut Odum (1994), yaitu : <D < 0,5 $=$ Tidak ada jenis yang mendominasi; $0,5 \leq \mathrm{D} \leq 1$ $=$ Terdapat jenis yang mendominasi.

\section{Analisis Nitrat dan Fosfat}

Parameter PO4-P menggunakan metode asam askorbat menggunakan spektrofotometer 
(SNI 2005:06-6989.31-2005) dengan panjang gelombang $810 \mathrm{~nm}$, parameter NO3-N menggunakan metode brusin sulfat (SNI 1991:062480-1991) menggunakan Spektrofotometer dengan panjang gelombang $420 \mathrm{~nm}$.

Pengukuran parameter kualitas air Menggunakan metode dan alat yang disajikan dalam Tabel 1.

\section{Analisis Data Penunjang}

Kecepatan dan arah arus diukur menggunakan Current meter. Data kecepatan dan arah arus selanjutnya diuraikan menjadi komponen arus $\mathrm{U}$ (sumbu $\mathrm{x}$ ) dan komponen $\mathrm{V}$ (sumbu $\mathrm{y}$ ). Besar komponen $\mathrm{U}$ dan $\mathrm{V}$ didapat rumus :

$$
\begin{aligned}
& \mathrm{U}=\mathrm{V}_{\text {total }} \operatorname{Sin}\left(\frac{\operatorname{Dir} \pi}{180}\right) \\
& \mathrm{V}=\mathrm{V}_{\text {total }} \operatorname{Cos}\left(\frac{\operatorname{Dir} \pi}{180}\right)
\end{aligned}
$$

Keterangan: $\pi=3,14$; Dir $=$ arah arus

\section{Analisis Data Sebaran dan Tumpang Susun}

Keterkaitan kandungan nitrat dan fosfat terhadap populasi fitoplankton dilakukan dengan menggunakan Metoda ArcGIS 10.3 yang akan di overlay, yang selanjutnya disusun dalam bentuk peta tumpang susun.

\section{HASIL DAN PEMBAHASAN}

Hasil pengamatan kandungan nitrat pada 9 stasiun penelitian di Muara Sungai Bodri berada pada kisaran 0,49-0,9 mg/l (Gambar 1). Hasil analisis kandungan fosfat pada 9 stasiun penelitian di Muara Sungai Bodri berkisar antara 0,01-0,29 $\mathrm{mg} / \mathrm{l}$ (Gambar 2).

\section{Struktur Populasi Fitoplankton}

Hasil pengamatan struktur populasi fitoplankton menunjukkan 4 kelas dan 45 species berdasarkan tanggal dan stasiun sampling disajikan pada Gambar 2, 3 dan 4. Berdasarkan jenis fitoplankton yang ditemukan berdasarkan tanggal dan stasiun sampling terdapat 14 species dengan kemunculan pada lebih dari 5 stasiun. Pada Kelas Bacillariophyceae, dijumpai Bacteriastrum sp., Cerataulus sp., Chaetoceros sp., Coscinodiscus sp., Eucampia sp., Gyrogsima sp., Nitzschia sp., Pleurosigma sp., Rhizosolenia sp., dan Thalassiothrix sp. Sedang jenis Ceratium sp. dan Prorocentrum sp. adalah dari Kelas Dinophyceae serta Leprotintinnus sp. dan Tintinnopsis sp adalah dari Kelas Oligotrichea.
Hasil pengamatan terhadap kelimpahan fitoplankton pada tanggal sampling 30 Juni 2018 terrendah dicapai pada stasiun 7 dengan kisaran jumlah 2.356 - $11.110 \mathrm{sel} / \mathrm{l}$, dengan rata - rata $6.403 \pm 3.443 \mathrm{sel} / \mathrm{l}$ dan tertinggi pada stasiun 3 dengan kisaran jumlah $2.356-63.636 \mathrm{sel} / \mathrm{l}$, dengan rata - rata $18.359 \pm 11.605 \mathrm{sel} / \mathrm{l}$. Selanjutnya sampling 1 September 2018 menunjukkan bahwa kelimpahan fitoplankton terrendah dicapai pada stasiun 4 dengan kisaran jumlah $2.356-11.784$ sel/l, dengan rata - rata $6.867 \pm 3.252 \mathrm{sel} / \mathrm{l}$ dan tertinggi pada stasiun 5 dengan kisaran jumlah 3.535 - $162.626 \mathrm{sel} / \mathrm{l}$, dengan rata - rata $21.219 \pm$ $23.225 \mathrm{sel} / \mathrm{l}$. Kelimpahan plankton pada sampling 27 Oktober 2018 menunjukkan bahwa nilai terrendah dicapai pada stasiun 6 dengan kisaran jumlah 2.200 - $23.225 \mathrm{sel} / \mathrm{l}$, dengan rata - rata $6.738 \pm 3.889 \mathrm{sel} / \mathrm{l}$ dan tertinggi pada stasiun 5 dengan kisaran jumlah 2.749 - $59.943 \mathrm{sel} / \mathrm{l}$, dengan rata - rata $13.244 \pm 12.699 \mathrm{sel} / \mathrm{l}$. Hasil kelimpahan selengkapnya disajikan pada Tabel $2 ; 3$ dan 4 , serta persebarannya disajikan pada Gambar 3 .

Hasil analisis keanekaragaman menunjukkan bahwa sampling tanggal 30 Juni 2018 nilai terrendah dicapai stasiun 3 dengan nilai 2,1081 dan tertinggi pada stasiun 5 dengan nilai 2,9162. Sedangkan hasil sampling tanggal 1 September 2018, menunjukkan bahwa nilai keanekaragaman terrendah dicapai stasiun 5 dengan nilai 1,4017 dan tertinggi pada stasiun 1 dengan nilai 2,3921. Nilai keanekaragaman hasil sampling tanggal 27 Oktober 2018 menunjukkan bahwa nilai keanekaragaman terrendah dicapai stasiun 2 dengan nilai 2,0547 dan tertinggi pada stasiun 9 dengan nilai 2,7227. Hasil analisis keanekaragaman selengkapnya berdasarkan tanggal sampling dan stasiun disajikan pada Gambar 3.

Nilai keseragaman sampling tanggal 30 Juni 2018 nilai terrendah dicapai stasiun 3 dengan nilai 0,7988 dan tertinggi pada stasiun 6 dengan nilai 0,9709 . Sedangkan hasil sampling tanggal 1 September 2018, menunjukkan bahwa nilai keseragaman terrendah dicapai stasiun 5 dengan nilai 0,5465 dan tertinggi pada stasiun 1 dengan nilai 0,9326 . Nilai keseragaman hasil sampling tanggal 27 Oktober 2018 menunjukkan bahwa nilai keanekaragaman terrendah dicapai stasiun 3 dengan nilai 0,8411 dan tertinggi pada stasiun 6 dengan nilai 0,9724. Hasil analisis keanekaragaman selengkapnya berdasarkan tanggal sampling dan stasiun disajikan pada Gambar 3. 


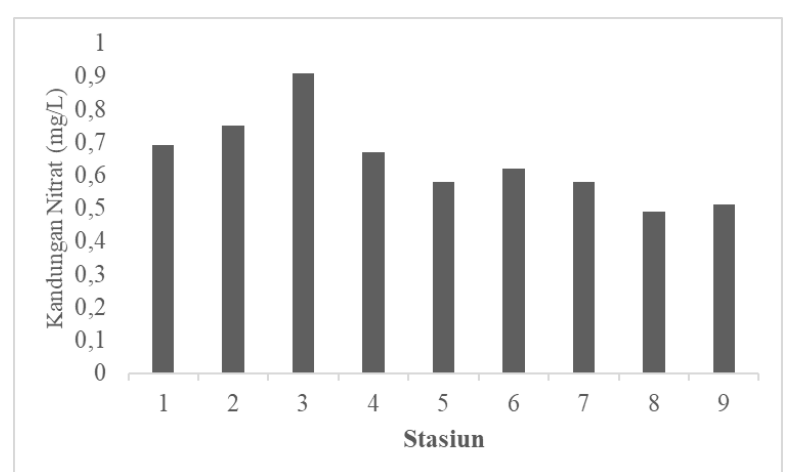

(a)

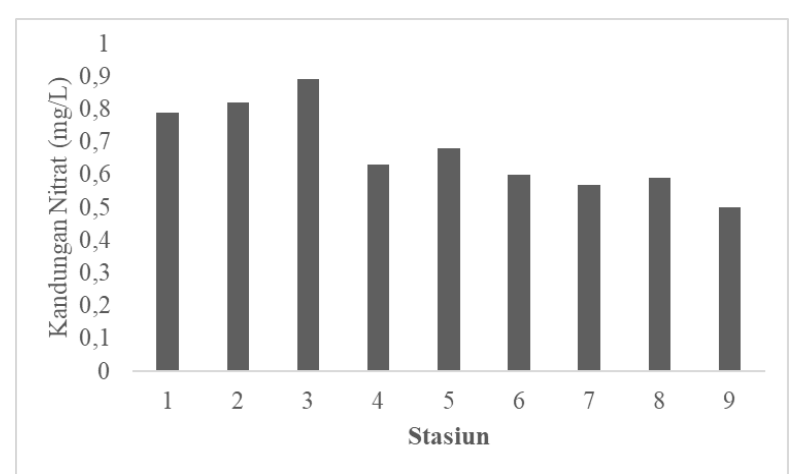

(b)

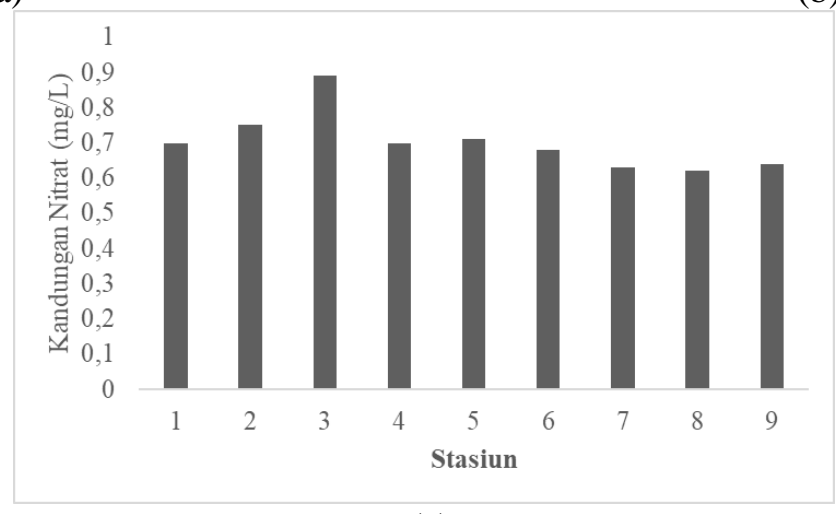

(c)

Gambar 1. Kandungan nitrat (mg./L) berdasarkan tanggal sampling 30 Juni (a), 1 September (b) dan 27 Okrober 2018 (c) di Muara Sungai Bodri, Kendal

Hasil analisis nilai dominansi menunjukkan bahwa sampling tanggal 30 Juni 2018, nilai terendah dicapai stasiun 6 dengan nilai 0,0602 dan tertinggi pada stasiun 2 dengan nilai 0,1669 . Sedangkan hasil sampling tanggal 1 September 2018, menunjukkan bahwa nilai dominansi terrendah dicapai stasiun 9 dengan nilai 0,0723 dan tertinggi pada stasiun 2 dengan nilai 0,1812 . Nilai dominasi hasil sampling tanggal 27 Oktober 2018 menunjukkan bahwa nilai keanekaragaman terrendah dicapai stasiun 6 dengan nilai 0,0719 dan tertinggi pada stasiun 2 dengan nilai 0,1812. Hasil analisis keanekaragaman selengkapnya berdasarkan tanggal sampling dan stasiun disajikan pada Gambar 3. Secara keseluruhan hasil analisis menunjukkan bahwa pada stasiun stasiun dengan nilai keseragaman tinggi, menunjukkan dapat terjadinya nilai keanekaragaman yang tinggi pula. Sedangkan pada stasiun stasiun dengan nilai keanekaragaman tinggi, menunjukkan nilai dominansi yang rendah.

Hasil pengamatan terhadap kandungan nitrat dan kelimpahan fitoplankton pada sampling tanggal 30 Juni 2018 membentuk pola yang berbeda, dimana kandungan nitrat sejalan dengan garis pantai, sedangkan kelimpahan fitoplankton berbentuk konvergen (Gambar 4). Kandungan nitrat membentuk sebaran mengikuti garis pantai pada stasiun 1, 2, 3, 4 dan 6, serta mengalami pembelokan kearah utara pada stasiun 5, 7, 8 dan 9. Kelimpahan fitoplankton membentuk sumbu konvergen pada stasiun 5. Sedangkan stasiun 1, 2 dan 3 terkait dengan pola garis pantai. Selanjutnya stasiun $4,6,7,8$, dan 9 membentuk pola divergen yang melebar, mengikuti sumbu pada stasiun 5 . Pola tersebut diperjelas dengan gambar tumpang susun diantara kandungan nitrat dan arah arus (Gambar 4, 5, dan 6).

Hasil analisis kandungan nitrat pada 9 stasiun menunjukkan bahwa nilai berkisar 0,49-0,9 mg/l (Gambar 1). Kandungan tersebut menunjukkan suplai nitrat yang cukup tinggi sehingga tergolong kedalam kriteria perairan dengan tingkat kesuburan eutrofik. Menurut Kusumaningtyas (2010) Penggolongan perairan berdasarkan tingkat kesuburan antara lain Perairan oligotrofik memiliki kadar nitrat $0-1 \mathrm{mg} / \mathrm{L}$, perairan mesotrofik memiliki kadar memiliki kadar nitrat antara 1-5 $\mathrm{mg} / \mathrm{L}$, dan perairan eutrofik memiliki kadar nitrat antara 5-50 mg/L Hal ini sejalan dengan penelitian Patty et. al. (2015), Utami et. al. (2016) dan 
Kurniawan et. al. (2016) yang menyatakan bahwa kandungan nitrat diatas $0.015 \mathrm{mg} / \mathrm{l}$ dikategorikan kedalam perairan dengan tingkat kesuburan yang tinggi. Kandungan nitrat membentuk sebaran mengikuti garis pantai pada stasiun 1, 2, 3, 5 dan 6, dari Timur menuju Barat Daya serta mengalami pembelokan kearah utara pada stasiun 4, 7, 8 dan 9 (Gambar 4,5 dan 6). Pola tersebut terjadi secara umum pada 3 perioda sampling, yang menunjukkan bahwa sebaran kandungan nitrat diakibatkan oleh pengaruh kondisi garis pantai, kedalaman serta kecerahan, dan suplai dari wilayah daratan. Hal ini dijelaskan oleh Domingues et. al. ( 2011), Kramer (2014), dan Cira et. al. (2016) yang menyatakan bahwa bila pada suatu perairan terjadi proses peningkatan kadar nitrat sebagai akibat suplai bahan organik yang terus menerus, akan mengakibatkan perairan tersebut menjadi suatu perairan yang eutrofik. Hal tersebut terjadi sebagai akibat suplai bahan organik dari daratan, proses

Tabel 1. Pengukuran Parameter Kualitas Air yang Dikaji Pada Penelitian

\begin{tabular}{|c|c|c|c|}
\hline Pengukuran & Parameter & Alat & Keterangan \\
\hline \multirow{5}{*}{ In-situ } & Suhu & Water Quality Checker & APHA, 2005 \\
\hline & Kecerahan & Secchi Disk & APHA, 2005 \\
\hline & $\mathrm{pH}$ & Water Quality Checker & Alaerts dan Santika, 1987 \\
\hline & Salinitas & Water Quality Checker & APHA, 2005 \\
\hline & $\begin{array}{l}\text { Dissolved } \\
\text { (DO) }\end{array}$ & DO Meter & Alaerts dan Santika, 1987 \\
\hline
\end{tabular}

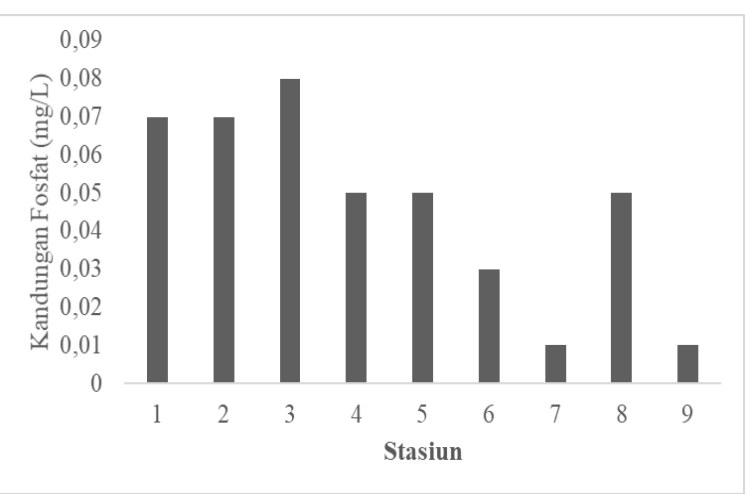

(a)

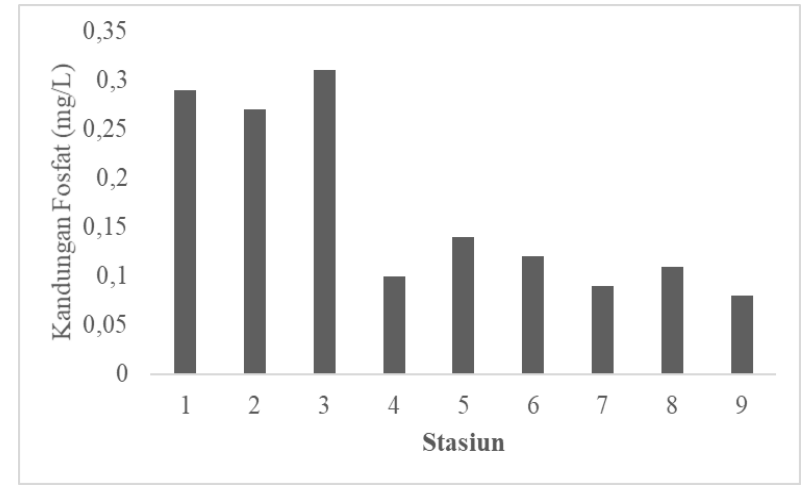

(b)

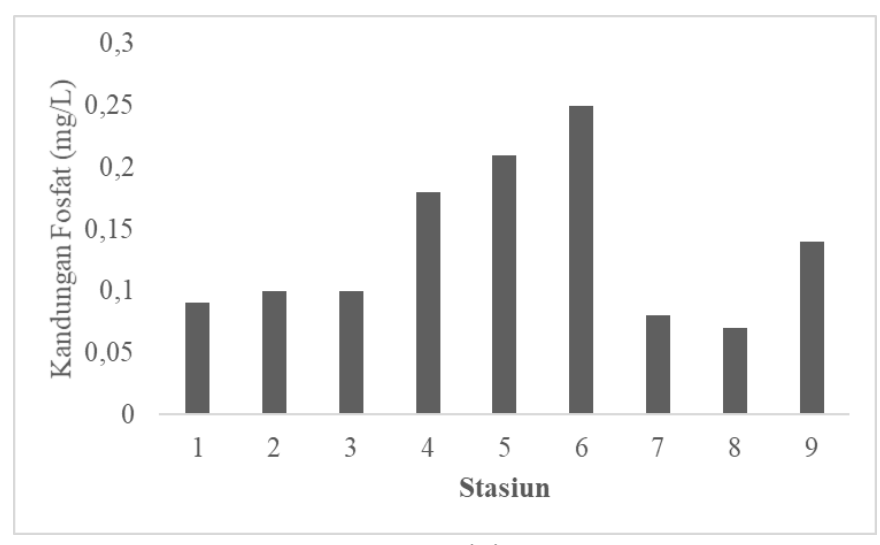

(c)

Gambar 2. Kandungan Fosfat (mg/l) berdasarkan tanggal sampling 30 Juni (a), 1 September (b) dan 27 Oktober 2018 (c) di Muara Sungai Bodri, Kendal 
Tabel 2. Kelimpahan Fitoplankton (sel / L ) Sampling 30 Juni 2018 di Muara Sungai Bodri, Kendal

\begin{tabular}{|c|c|c|c|c|c|c|c|c|c|}
\hline \multirow{2}{*}{ Kelas dan Species } & \multicolumn{9}{|c|}{ Stasiun } \\
\hline & 1 & 2 & 3 & 4 & 5 & 6 & 7 & 8 & 9 \\
\hline \multicolumn{10}{|l|}{ Bacillariophyceae } \\
\hline Asterionella sp. & - & - & - & - & - & - & - & 2,356 & - \\
\hline Bacteriastrum sp. & - & - & 7.070 & 8.973 & 5.656 & 10,605 & - & 3,535 & 11,931 \\
\hline Biddulphia sp. & - & - & - & - & - & - & & - & - \\
\hline Cerataulus sp. & 10.605 & 8.973 & - & 7.070 & 8.973 & 10.605 & 5.656 & - & - \\
\hline Chaetoceros sp. & 20.033 & 11.110 & 11.931 & 11.194 & 14.141 & 10.677 & 8.973 & 7.070 & 16.498 \\
\hline Climacosphenia sp. & - & - & - & - & - & - & 7.070 & - & - \\
\hline Climacodium sp. & - & - & - & 4.713 & 7.070 & - & - & - & - \\
\hline Climacosphenia sp. & - & 5.656 & - & 3.535 & - & - & - & - & - \\
\hline Cocconeis sp. & - & - & 2.356 & - & - & 2.356 & - & - & - \\
\hline Coscinodiscus sp. & 21.212 & 7.070 & 3.535 & 9.427 & 11.784 & 5.656 & 10.605 & 3.535 & 4.713 \\
\hline Cylindrotheca sp. & - & & - & - & - & - & - & - & - \\
\hline Diploneis sp. & 7.070 & - & - & - & 7.070 & - & - & - & 4.713 \\
\hline Eucampia sp. & 7.070 & 5.656 & - & - & - & - & 4.713 & 7.070 & 8.973 \\
\hline Fragilaria $\mathrm{sp}$. & - & - & - & - & - & 8.973 & - & - & 11.110 \\
\hline Guinardia sp. & 5.656 & - & - & - & 8.973 & - & - & - & - \\
\hline Gyrogsima sp. & 35.353 & 3.535 & - & - & 11.931 & 3.535 & 2.356 & - & 3.535 \\
\hline Isthmia sp. & - & 8.973 & - & - & 7.070 & 5.656 & - & - & 5.656 \\
\hline Nitzschia sp. & 27.104 & 11.110 & 31.818 & 8.973 & 14.141 & 7.353 & 11.110 & 8.973 & 10.677 \\
\hline Pleurosigma sp. & 15.908 & 5.892 & - & 9.427 & 11.784 & 8.484 & 2.356 & 12.373 & 7.070 \\
\hline Pseudo-Nitzschia sp. & - & - & 2.356 & - & - & - & - & 2.356 & - \\
\hline Rhabdonema sp. & - & - & - & - & 14.141 & - & - & 3.535 & - \\
\hline Rhizosolenia sp. & 26.599 & 32.458 & 29.873 & 7.353 & 50.096 & 5.656 & 10.723 & 14.141 & 13.787 \\
\hline Skeletonema sp. & - & - & 5.656 & 4.713 & - & - & - & - & - \\
\hline Streptotheca sp. & - & - & 3.535 & - & & - & 3.535 & - & 8.973 \\
\hline Thalassionema sp. & - & - & 63.636 & - & - & - & - & - & - \\
\hline Thalassiosira sp. & - & - & - & - & 14.141 & - & - & - & 3.535 \\
\hline Thalassiothrix sp. & 14.141 & 7.070 & - & 2.356 & 35.353 & 11.312 & 2.356 & 10.605 & 14.141 \\
\hline Triceratium revale & - & - & - & - & 5.656 & - & - & - & - \\
\hline \multicolumn{10}{|l|}{ Dinophyceae } \\
\hline Trichodesmium sp. & - & - & - & - & 26.599 & - & - & 14.141 & 3.535 \\
\hline Gymnodinium sp. & - & - & - & 8.973 & - & 2.828 & 4.713 & - & - \\
\hline Amphisolenia sp. & - & - & - & - & 14.141 & - & - & - & - \\
\hline Ceratium sp. & 14.141 & 12.373 & 11.784 & 4.713 & 13.787 & 7.777 & 5.184 & 7.070 & 7.070 \\
\hline Prorocentrum sp. & - & - & - & 2.828 & 50.096 & 4.713 & 9.427 & - & 8.973 \\
\hline Protoperidinium sp. & 14.141 & - & - & - & - & - & - & - & - \\
\hline Pyrocystic sp. & 14.141 & - & 21.212 & - & 14.141 & - & - & - & - \\
\hline Pyrophacus sp. & - & - & - & - & - & - & - & 5.656 & 3.535 \\
\hline Spatulodinium sp. & - & - & - & - & - & - & - & - & - \\
\hline Halosphaera sp. & - & - & - & - & - & - & - & & - \\
\hline Epiplocylis sp. & - & - & & - & - & - & - & - & - \\
\hline Leprotintinnus sp. & - & - & 2.356 & 4.713 & 26.599 & 8.973 & 3.534 & 3.535 & 2.356 \\
\hline Poroecus sp. & - & - & - & - & & - & - & - & - \\
\hline Tintinnopsis sp. & - & 17.676 & 4.418 & 2.356 & 14.141 & 5.656 & 2.356 & 3.535 & 10.606 \\
\hline
\end{tabular}


Tabel 3. Kelimpahan Fitoplankton (sel / L ) Sampling 1 September 2018 di Muara Sungai Bodri, Kendal

\begin{tabular}{|c|c|c|c|c|c|c|c|c|c|}
\hline \multirow{2}{*}{ Kelas dan Species } & \multicolumn{9}{|c|}{ Stasiun } \\
\hline & 1 & 2 & 3 & 4 & 5 & 6 & 7 & 8 & 9 \\
\hline \multicolumn{10}{|l|}{ Bacillariophyceae } \\
\hline Asterionella sp. & - & - & - & - & - & - & - & 2,356 & - \\
\hline Bacteriastrum sp. & - & - & 7.070 & 8.973 & 5.656 & 10,605 & - & 3,535 & 11,931 \\
\hline Cerataulus sp. & 10.605 & 8.973 & - & 7.070 & 8.973 & 10.605 & 5.656 & - & - \\
\hline Chaetoceros sp. & 20.033 & 11.110 & 11.931 & 11.194 & 14.141 & 10.677 & 8.973 & 7.070 & 16.498 \\
\hline Climacosphenia sp. & - & - & - & - & - & - & 7.070 & - & - \\
\hline Climacodium sp. & - & - & - & 4.713 & 7.070 & - & - & - & - \\
\hline Climacosphenia sp. & - & 5.656 & - & 3.535 & - & - & - & - & - \\
\hline Cocconeis sp. & - & - & 2.356 & - & - & 2.356 & - & - & - \\
\hline Coscinodiscus sp. & 21.212 & 7.070 & 3.535 & 9.427 & 11.784 & 5.656 & 10.605 & 3.535 & 4.713 \\
\hline Cylindrotheca sp. & - & & - & - & - & - & - & - & - \\
\hline Diploneis sp. & 7.070 & - & - & - & 7.070 & - & - & - & 4.713 \\
\hline Ditylum sp. & - & & - & - & - & - & - & - & - \\
\hline Eucampia sp. & 7.070 & 5.656 & - & - & - & - & 4.713 & 7.070 & 8.973 \\
\hline Fragilaria sp. & - & - & - & - & - & 8.973 & - & - & 11.110 \\
\hline Guinardia sp. & 5.656 & - & - & - & 8.973 & - & - & - & - \\
\hline Gyrogsima sp. & 35.353 & 3.535 & - & - & 11.931 & 3.535 & 2.356 & - & 3.535 \\
\hline Isthmia sp. & - & 8.973 & - & - & 7.070 & 5.656 & - & - & 5.656 \\
\hline Nitzschia sp. & 27.104 & 11.110 & 31.818 & 8.973 & 14.141 & 7.353 & 11.110 & 8.973 & 10.677 \\
\hline Pleurosigma & 15.908 & 5.892 & - & 9.427 & 11.784 & 8.484 & 2.356 & 12.373 & 7.070 \\
\hline Pseudo-Nitzschia sp. & - & - & 2.356 & - & - & - & - & 2.356 & - \\
\hline Rhabdonema sp. & - & - & - & - & 14.141 & - & - & 3.535 & - \\
\hline Rhizosolenia sp. & 26.599 & 32.458 & 29.873 & 7.353 & 50.096 & 5.656 & 10.723 & 14.141 & 13.787 \\
\hline Skeletonema sp. & - & - & 5.656 & 4.713 & - & - & - & - & - \\
\hline Streptotheca sp. & - & - & 3.535 & - & & - & 3.535 & - & 8.973 \\
\hline Thalassionema sp. & - & - & 63.636 & - & - & - & - & - & - \\
\hline Thalassiosira sp. & - & - & - & - & 14.141 & - & - & - & 3.535 \\
\hline Thalassiothrix $\mathrm{s}$ & 14.141 & 7.070 & - & 2.356 & 35.353 & 11.312 & 2.356 & 10.605 & 14.141 \\
\hline Triceratium revale & - & - & - & - & 5.656 & - & - & - & - \\
\hline Actinocyclus sp. & - & - & - & - & - & - & - & - & - \\
\hline \multicolumn{10}{|l|}{ Dinophyceae } \\
\hline Trichodesmium sp. & - & - & - & - & 26.599 & - & - & 14.141 & 3.535 \\
\hline Gymı & - & - & - & 8.973 & - & 2.828 & 4.713 & - & - \\
\hline Amphisolenia sp. & - & - & - & - & 14.141 & - & - & - & - \\
\hline Ceratium sp. & 14.141 & 12.373 & 11.784 & 4.713 & 13.787 & 7.777 & 5.184 & 7.070 & 7.070 \\
\hline ntrum sp. & - & - & - & 2.828 & 50.096 & 4.713 & 9.427 & - & 8.973 \\
\hline Protoperidinium sp. & .141 & - & - & - & - & - & - & - & - \\
\hline Pyrocystic sp. & 14.141 & - & 21.212 & - & 14.141 & - & - & - & - \\
\hline Pyrophacus sp. & - & - & - & - & - & - & - & 5.656 & 3.535 \\
\hline Spatulodinium sp. & - & - & - & - & - & - & - & - & - \\
\hline Halosphaera sp. & - & - & - & - & - & - & - & & - \\
\hline Epiplocylis sp. & - & - & & - & - & - & - & - & - \\
\hline Leprotintinnus sp. & - & - & 2.356 & 4.713 & 26.599 & 8.973 & 3.534 & 3.535 & 2.356 \\
\hline Poroecus sp. & - & - & - & - & & - & - & - & - \\
\hline Tintinnopsis sp. & - & 17.676 & 4.418 & 2.356 & 14.141 & 5.656 & 2.356 & 3.535 & 10.606 \\
\hline
\end{tabular}


Tabel 4. Kelimpahan Fitoplankton (sel / L ) Sampling 27 Oktober 2018 di Muara Sungai Bodri, Kendal

\begin{tabular}{|c|c|c|c|c|c|c|c|c|c|}
\hline \multirow{2}{*}{ Kelas dan Genus } & \multicolumn{9}{|c|}{ Stasiun } \\
\hline & 1 & 2 & 3 & 4 & 5 & 6 & 7 & 8 & 9 \\
\hline \multicolumn{10}{|l|}{ Bacillariophyceae } \\
\hline Asterionella sp. & - & - & 3.666 & - & 2.749 & - & 5.499 & & - \\
\hline Bacteriastrum sp. & - & - & 5.499 & 5.499 & - & 10.999 & - & 2.749 & 13.748 \\
\hline Biddulphia sp. & 2.749 & - & - & 2.749 & - & - & 1.832 & - & - \\
\hline Cerataulus sp. & 10.999 & - & - & - & 10.999 & 10.999 & 3.666 & - & - \\
\hline Chaetoceros sp. & 15.581 & 8.641 & 9.280 & 9.280 & 15.712 & 8.248 & 6.979 & 5.499 & 12.832 \\
\hline Climacosphenia sp. & - & - & - & - & - & - & - & - & - \\
\hline Climacodium sp. & - & - & - & - & - & - & - & - & - \\
\hline Climacosphenia sp. & - & - & - & - & - & - & - & - & - \\
\hline Cocconei & - & - & - & - & - & - & - & - & - \\
\hline Coscinodiscus sp. & 16.498 & 5.499 & 2.749 & 7.332 & 9.165 & 4.399 & 10.082 & 2.749 & 5.499 \\
\hline Cylindrotheca sp. & - & - & - & - & - & - & - & - & - \\
\hline Diploneis sp. & 2.749 & - & - & 3.666 & - & 4.399 & - & - & 5.499 \\
\hline Ditylum sp. & - & - & - & - & - & - & - & - & - \\
\hline Eucampia sp. & 5.499 & - & - & 2.749 & - & - & 3.666 & - & - \\
\hline Fragilaria sp. & - & - & - & - & - & - & - & - & - \\
\hline Guinardia sp. & - & - & - & - & - & - & - & - & - \\
\hline Gyrogsima sp. & - & 2.749 & - & - & 10.999 & 4.399 & - & 3.666 & - \\
\hline Isthmia sp. & - & 8.249 & - & - & 2.749 & - & - & - & 5.499 \\
\hline Nitzschia sp. & 32.996 & - & 24.747 & 5.805 & 21.081 & - & 14.054 & 8.248 & - \\
\hline Pleurosigma & 12.373 & 4.583 & - & 7.332 & 9.165 & 6.599 & 1.832 & 9.623 & 5.499 \\
\hline Pseudo-Nitzschia & - & - & 4.124 & - & 3.666 & - & - & 2.749 & - \\
\hline Rhabdonem & - & - & 2.749 & 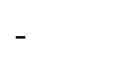 & 16.498 & - & - & 2.749 & - \\
\hline Rhizos & 31.827 & 38.839 & 35.746 & 8.798 & 59.943 & 5.499 & 12.831 & 21.080 & 16.497 \\
\hline Skeletonema sp. & - & - & 6.599 & - & - & 4.124 & - & - & 3.666 \\
\hline Streptotheca sp. & - & 4.124 & - & - & 5.805 & - & - & 2.749 & 6.599 \\
\hline Thalassionema $\mathrm{sp}$ & - & - & 49.495 & - & - & - & - & 35.746 & - \\
\hline Thalassiosira sp. & - & - & 4.583 & - & 8.249 & - & - & 10.999 & - \\
\hline Thalassiothrix sp. & 16.498 & 7.332 & 8.249 & 4.583 & 10.999 & 9.165 & 7.332 & 9.623 & 10.999 \\
\hline \multicolumn{10}{|l|}{ Dinophyceae } \\
\hline Trichodesmium sp. & - & - & 9.165 & - & 21.997 & - & - & 8.249 & 2.749 \\
\hline Gymnodinium sp. & 2.749 & - & 4.399 & 9.165 & - & 2.200 & 3.666 & - & 8.249 \\
\hline Amphisolenia sp. & - & - & 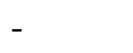 & & & & 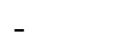 & - & - \\
\hline Ceratium sp. & 16.497 & 9.623 & 9.165 & 3.666 & 16.498 & & 4.032 & 5.499 & 5.499 \\
\hline Prorocentrum sp. & - & - & - & 4.124 & 5.805 & 6.599 & 5.805 & 8.249 & 7.332 \\
\hline Protoperidinium $\mathrm{s}$ & 10.999 & - & - & 12.831 & - & - & 4.399 & - & - \\
\hline Pyrocystic sp. & 6.599 & - & 7.332 & 4.583 & - & 5.805 & 5.499 & - & 6.049 \\
\hline Pyrophacus sp. & - & - & - & - & - & - & - & - & - \\
\hline Halosphaera sp. & - & - & - & - & - & - & - & - & - \\
\hline Epiplocylis sp. & - & - & - & - & - & - & - & - & - \\
\hline Leprotintinnus sp. & 2.749 & 3.666 & 4.583 & 16.498 & 14.054 & 10.999 & 2.749 & 2.749 & 4.124 \\
\hline Poroecus sp. & - & - & - & - & - & - & - & - & - \\
\hline Tintinnopsis sp. & 4.399 & 13.748 & 3.436 & 1.832 & 5.499 & 7.332 & 1.832 & 2.749 & 8.249 \\
\hline
\end{tabular}




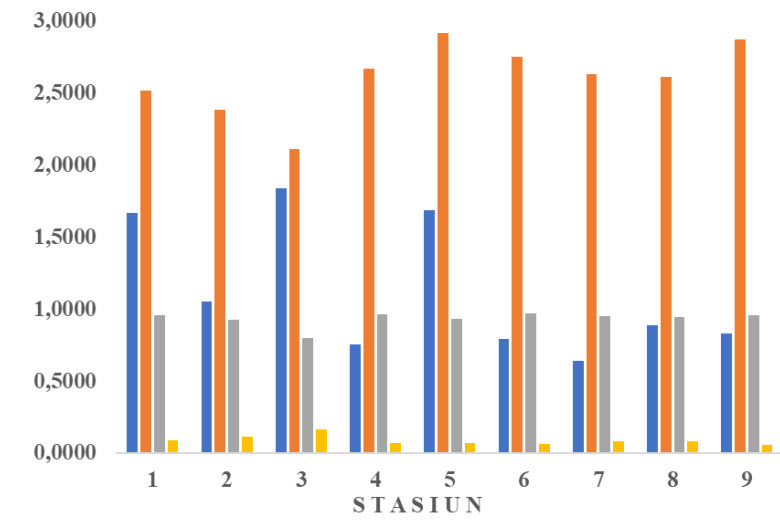

(a)

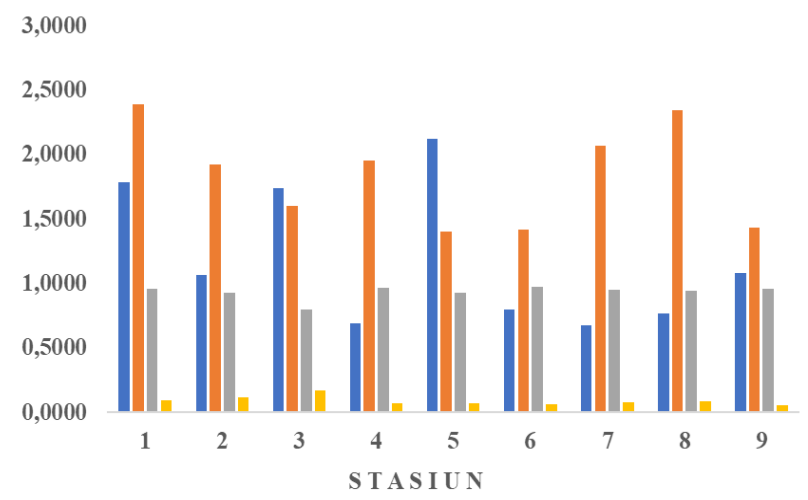

(b)

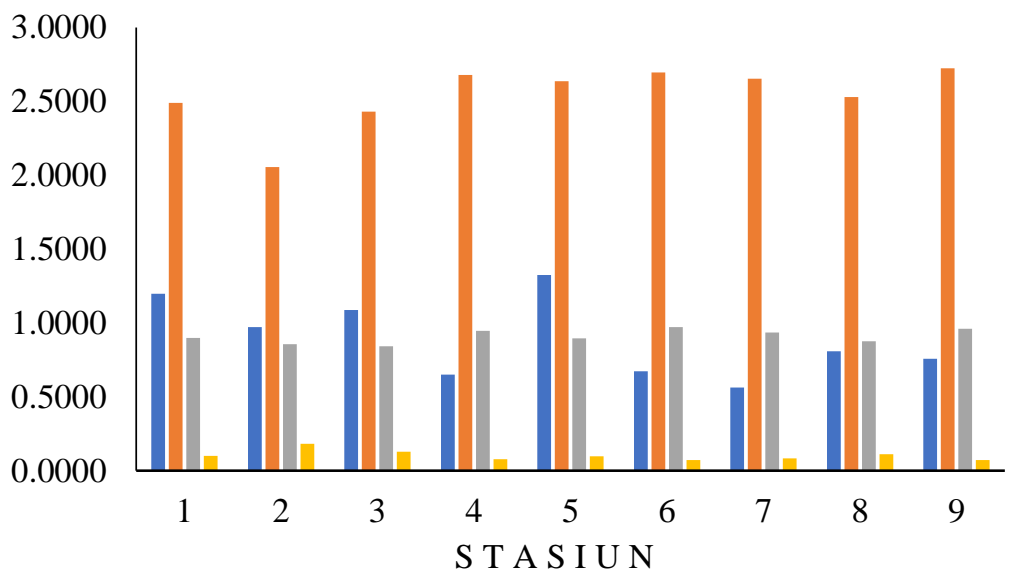

-Kelimpahan $₫$ Keanekaragaman $\llbracket$ Keseragaman $\llbracket$ Dominansi

(c)

Gambar 3. Grafik kelimpahan plankton rata rata ( x $10^{4} \mathrm{sel} / 1$ ), keanekaragaman $(\mathrm{H})$, keseragaman (E) dan dominansi (D) ) berdasarkan tanggal sampling 30 Juni (a), 1 September (b) dan 27 Oktober 2018 (c) di Muara Sungai Bodri, Kendal

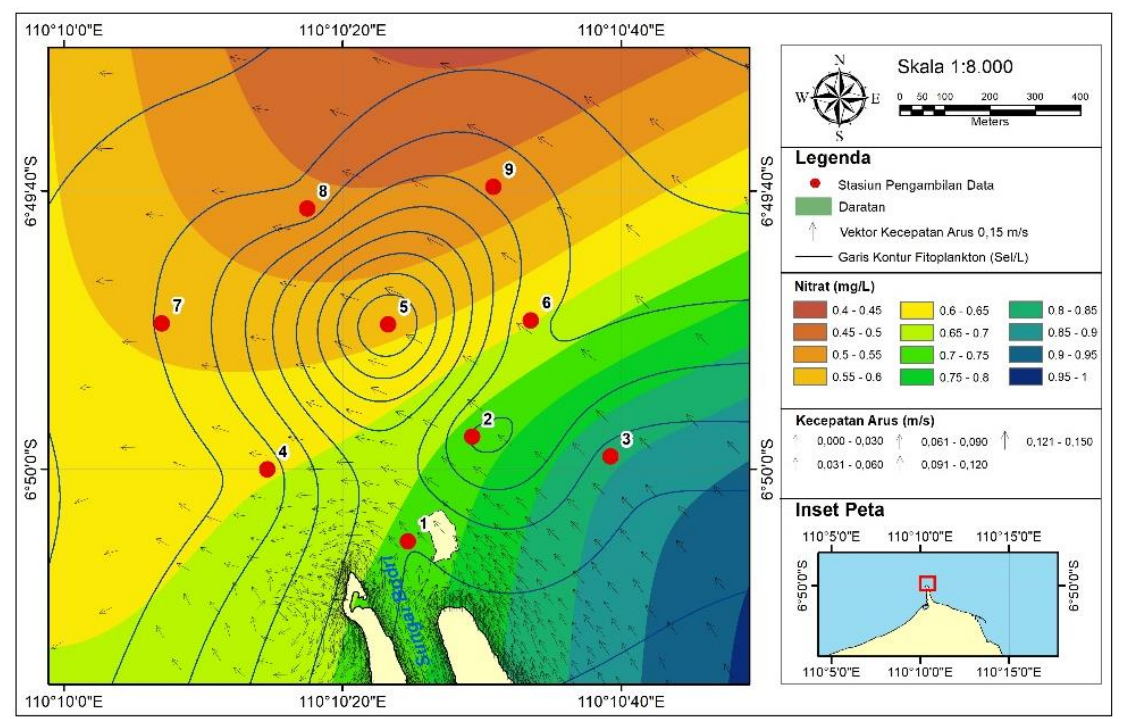

Gambar 4. Overlay antara fitoplankton, nitrat, dan pola arus tanggal 30 Juni 2018 di Muara Sungai Bodri, Kendal 


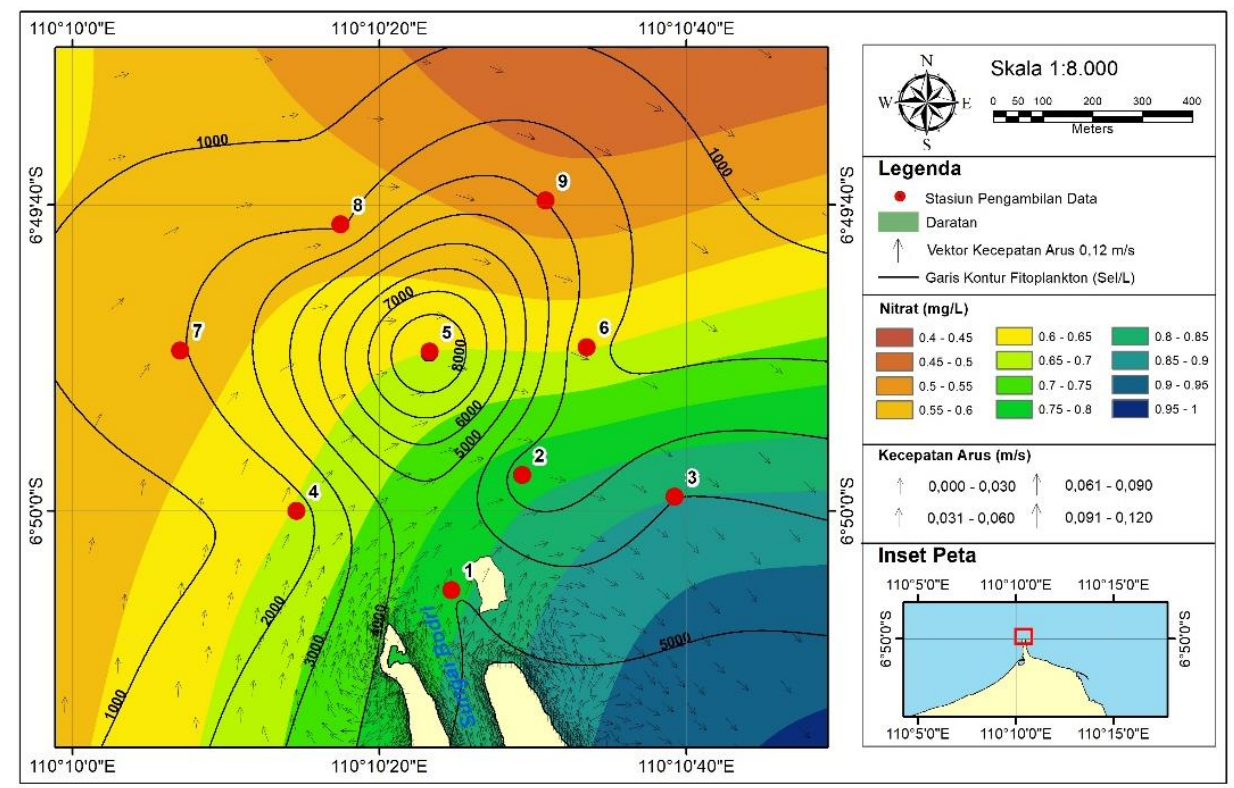

Gambar 5. Overlay antara fitoplankton, nitrat, dan pola arus tanggal 1 September 2018 di Muara Sungai Bodri, Kendal

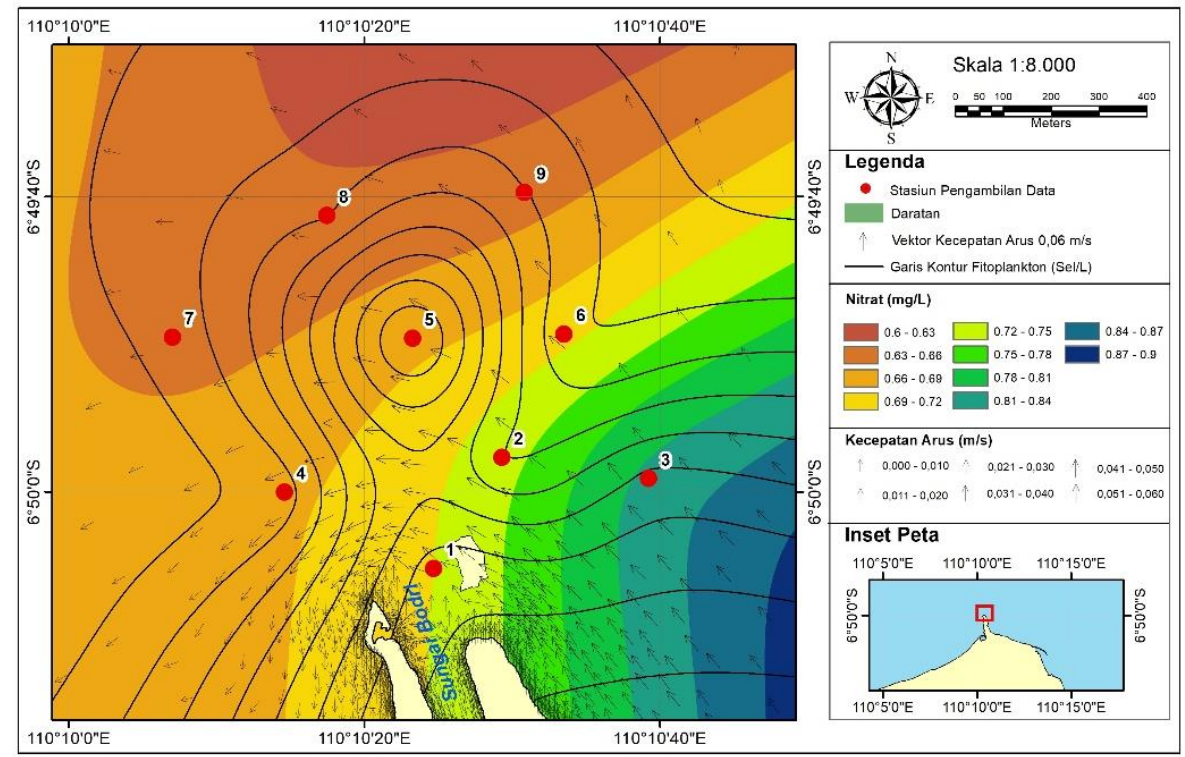

Gambar 6. Overlay antara fitoplankton, nitrat, dan pola arus tanggal 27 Oktober 2018 di Muara Sungai Bodri, Kendal

degradasi bahan organik menjadi unsur $\mathrm{N}$, serta, percampuran yang terjadi pada lapisan perairan maupun badan air yang diakibatkan oleh arus, pasang surut, kedalaman dan bentuk garis pantai yang secara interaktif terjadi secara simultan. Hal ini dijelaskan oleh Erickson III, et al., (2015), Maslukah, et al., (2019) bahwa Nitrat $\left(\mathrm{NO}_{3}{ }^{-}\right)$ merupakan senyawa dihasilkan dari proses oksidasi sempurna senyawa nitrogen di perairan. Oksidasi amonia menjadi nitrit dan nitrat berlangsung dalam kondisi aerobik. Konsentrasi nitrat di suatu perairan selain berasal dari proses nitrifikasi nitrit, juga berasal dari masukan limbah rumah tangga, limbah pertanian yang berupa sisa pemupukan, limbah peternakan sisa dari pakan, pengikatan nitrogen bebas dari udara oleh mikrobiota, limbah industri, dan aliran tanah yang masuk ke laut (Panagiotaras et al., 2015, Cermeño, et al., 2016).

Persebaran kandungan nitrat pada penelitian ini terbentuk pola divergen, pola ini terjadi pembalikan arah dari stasiun 9 ke 7, dari arah 
Timur menuju ke Utara atau Timur Laut, serta pembalikan arah dari stasiun 6 ke 4 dengan pembelokan dari arah Timur menuju ke arah Barat Daya, menunjukkan bahwa pada stasiun 5, merupakan area pembelokan atau divergensi dari persebaran tersebut (Gambar 4). Bila pola persebaran tersebut dianalisis tumpang susun dengan persebaran kelimpahan fitoplankton, menunjukkan bahwa pola divergensi kandungan nitrat yang terjadi pada stasiun 4 dan 7 , menjadikan terjadinya titik tumpu persebaran terjadi pada stasiun 5. Terlihat pada stasiun 8, 9, 6 dan 3, membentuk suatu pola melingkar dengan sumbu pada stasiun 5 (Gambar 4,5,6), menandakan bahwa persebaran nitrat, akan dimanfaatkan oleh fitoplankton sesuai perkembangan dan siklus hidupnya. Hasil overlay antara nitrat dan kelimpahan fitoplankton (Gambar 4, terlihat pola sebaran keduanya sama, sehingga dapat menjelaskan adanya keterkaitan pada stasiun 1,2, 3 dan 4). Sedangkan pada stasiun yang lain menunjukkan adanya variabel lain yang berpengaruh, seperti kedalaman misalnya. Hal ini dijelaskan Panagiotaras et al., (2015), serta Cermeño, et al., (2016) bahwa keberadaan nitrat di lapisan permukaan laut diatur oleh proses biologi dan fisika yang terjadi pada suatu perairan. Pemanfaatan nitrat oleh fitoplankton terjadi selama berlangsung proses fotosintesis dan tergantung pada intensitas sinar matahari. Hal tersebut menjelaskan bahwa antara kandungan nitrat dan kelimpahan fitoplankton terdapat pola - pola persebaran yang terjadi sesuai proses biogeokimia yang terjadi pada perairan tersebut.

Klasifikasi menurut Iswanto et al. (2015), Linus et al. (2016) dan Sidaningrat et al. (2018) menyatakan bahwa perairan dengan kelimpahan plankton $2.000-15.000$ ind/L diklasifikasikan mesotrofik, sedangkan dengan kelimpahan plankton > $15.000 \mathrm{ind} / \mathrm{L}$ masuk kedalam perairan eutrofik. Hal tersebut sesuai dengan hasil pengamatan terhadap kelimpahan fitoplankton pada tanggal sampling 30 Juni 2018 - 27 Oktober 2018. menunjukkan bahwa perairan Muara Kali Bodri, Kendal dapat diklasifikasikan menjadi perairan mesotrofik sampai eutrofik, karena kisaran kelimpahan $2.000->15.000 \mathrm{ind} / \mathrm{L}$. Hal ini tedapat keterkaitan kelimpahan plankton dengan kandungan nitrat dijelaskan oleh Muhaemin et al. (2014), bahwa nitrat merupakan faktor pembatas pada keberhasilan proses fotosintesa, terutama pada reaksi terang, dengan produk berupa oksigen. Zainuri (2010) dan Yuliana (2012) kelimpahan populasi fitoplankton terkait erat dengan unsur nutrien, khususnya nitrogen untuk mendukung proses respirasi dan asimilasi keberadaan biota fitoplankton

Kandungan nitrat, kelimpahan fitoplankton serta indeks kesuburan perairan sebagai indikator, juga dapat dijelaskan dengan indeks keanekaragaman, keseragaman dan dominansi. Hasil analisis nilai keanekaragaman pada struktur populasi fitoplankton di Muara Sungai Kali Bodri menunjukkan nilai kisaran diantara 2,1081 2,9162 pada perioda Juni $2018 ; 1,402-2,392$ pada perioda September 2018 serta 2,0547 - 2,7227 pada perioda Oktober 2018. Hasil keanekaragaman menunjukkan populasi fitoplankton mampu melakukan adaptasi dan strategi reproduksi terkait erat dengan kandungan nutrisi yang ada didalam perairan. Nilai keanekaragaman Juni 2018 dan oktober 2018 menandakan bahwa unsur nutrien, dalam hal ini nitrat, yang dibutuhkan oleh fitoplankton untuk melakukan reproduksi dapat terpenuhi. Sedangkan hasil yang berbeda ditunjukkan pada perioda September 2018, dengan nilai keanekaragaman yang lebih rendah. Hal ini terkait erat dengan faktor nutrien yang mengalami penurunan akibat perioda perubahan musim, dimana jumlah jenis dan kelimpahan mengalami penurunan akibat faktor limitasi unsur nutrien. Yuliana et al. (2012), menjelaskan bahwa indeks keanekaragaman merupakan intepretasi derajat kesuburan dengan mengkonversi kelimpahan serta fungsi jumlah jenis menjadi suatu skala indicator kesuburan perairan. Hasil nilai keanekaragaman populasi fitoplankton yang terjadi di Muara Sungai Bodri, Kendal, berada diantara sedang sampai dengan tinggi, yang dihasilkan dari ketersediaan unsur nutrien menunjukkan adanya keterkaitan diantara populasi fitoplankton, serta faktor fisika dan kimia perairan.

Hasil analisis nilai keseragaman fitoplankton menunjukkan bahwa kisaran diantara 0,7988 - 0,9709 pada perioda Juni $2018 ; 0,5465$ 0,9326 pada perioda September 2018 serta 0,8411 - 0,9724 pada perioda Oktober 2018. Nilai keseragaman tersebut menunjukkan pola yang sama dengan nilai keanekaragaman. Hasil nilai keseragaman perioda Juni dan Oktober 2018 menunjukkan kisaran yang relatif stabil, sedangkan perioda September 2018 menunjukkan dinamika yang cukup tinggi. Hal ini menunjukkan bahwa pada perioda September 2018 merupakan masa peralihan yang terkait dengan musim. Nilai keseragaman tersebut diklasifikasian kedalam 
perairan dengan nilai keseragaman tinggi, karena memiliki nilai diatas 0,6 (Mayagitha et al., 2014). Hal ini didukung oleh kandungan nutrien dan kondisi lingkungan yang mencukupi, sehingga memiliki kesempatan untuk berkembang dan reproduksi dengan optimal. Zainuri (2010), Cahyanti et al. (2014), bahwa keseragaman yang terjadi pada populasi fitoplankton terkait erat dengan kemampuan adaptasi serta strategi bertoleransi terhadap perubahan lingkungan. Hal tersebut bahwa indikator keseragaman bersama sama dengan indikator keanekaragaman dapat digunakan untuk menduga kesuburan perairan. Lebih lanjut ditambahkan dalam hal ini daya dukung dan daya tampung. Daya dukung untuk mendukung proses kehidupan fitoplankton, sedangkan daya tampung adalah kapasitas badan air untuk proses pertukaran biota terkait dengan lingkungan hidupnya. Hasil tersebut bahwa Muara Sungai Bodri, Kendal, mempunyai kapasitas dan daya dukung untuk mendukung kehidupan fitoplankton, dengan dipengaruhi oleh dinamika kualitas perairan.

Hasil analisis nilai dominansi menunjukkan menunjukkan bahwa kisaran diantara 0,0571 0,1812. Hasil tersebut menunjukkan bahwa tidak terjadi dominansi jenis fitoplankton tertentu. Hasil ini sebagaimana dinyatakan oleh Hutabarat et al. (2014), bahwa pada suatu perairan dengan indeks dominansi dibawah 0,5 menunjukkan bahwa pada perairan tersebut tidak terjadi dominansi dari satu species. Berdasarkan hasil penelitian ditemukan 14 jenis pada lebih dari 5 stasiun. Jenis - jenis fitoplankton tersebut adalah Kelas Bacillariophyceae, dijumpai Bacteriastrum sp., Cerataulus sp., Chaetoceros sp., Coscinodiscus sp., Eucampia sp., Gyrogsima sp., Nitzschia sp., Pleurosigma sp., Rhizosolenia sp., dan Thalassiothrix sp. Sedang jenis Ceratium sp. dan Prorocentrum sp. adalah dari Kelas Dinophyceae serta Leprotintinnus sp. dan Tintinnopsis sp adalah dari Kelas Oligotrichea. Jenis - jenis tersebut teramati dari sejumlah 5 kelas dan 45 genus total yang teridentifikasi di Muara Sungai Bodri, Kendal. Hasil tersebut menjelaskan bahwa kondisi fitoplankton dilokasi penelitian keberadaannya didukung oleh nutrient (Nitrat) untuk pertumbuhan dan perkembangannya. Zainuri (2010), Dewi et. al. (2017) dan Zainuri et. al. (2017) bahwa terjadinya dominansi fitoplankton terjadi saat eutrofikasi, yaitu terjadi lonjakan unsur nutrien dimanfaatkan oleh biota fitoplankton tertentu, namun hal tersebut justru menjadi pembatas bagi biota intoleran.
Berdasarkan jenis - jenis fitoplankton tersebut menunjukkan bahwa secara keseluruhan, setiap jenis fitoplankton dapat tumbuh dan berkembang hingga mencapai kelimpahan yang cukup optimal. Kondisi kandungan nutrien, dalam hal ini kandungan nitrat, serta kisaran kualitas perairan di Muara Sungai Bodri, Kendal, menjadi daya dukung dan memberikan daya tampung bagi setiap jenis untuk tumbuh dan berkembang secara optimal, dan tidak menimbulkan dominansi dari jenis fitoplankton tertentu.

\section{Hasil Analisis Sebaran Fosfat terhadap Kelimpahan Fitoplankton serta Pola Arus}

Hasil pengamatan terhadap kandungan fosfat dan kelimpahan fitoplankton membentuk pola yang berbeda. Kandungan fosfat pada perioda 30 Juni 2018 membentuk pola konvergen dengan sumbu pada stasiun 4 , yang berbentuk lingkaran berlapis hingga stasiun 1, 5, 7 dan 8 . Sedangkan pada stasiun 2, 3, 6 dan 9 membentuk pola distribusi paling luar (Gambar 7). Kelimpahan fitoplankton membentuk sumbu konvergen pada stasiun 5. Sedangkan stasiun 1, 2 dan 3 terkait dengan pola garis pantai. Selanjutnya stasiun 4,6 , 7 , 8, dan 9 membentuk pola divergen yang melebar, mengikuti sumbu pada stasiun 5. Pola tersebut diperjelas dengan gambar tumpang susun diantara kandungan fosfat dan arah arus (Gambar 8 dan 9).

Kandungan nitrat tersebut menunjukkan nilai yang cukup tinggi. Hal ini dijelaskan oleh Risamasu dan Prayitno (2011), Patty (2014), Patricia et. al. (2018) bahwa kandungan fosfat diatas $0.07 \mathrm{mg} / \mathrm{l}$ termasuk perairan yang subur. Menurut Patty et al. (2015) Klasifikasi tingkat Kesuburan Perairan berdasarkan Kadar Fosfat Fosfat (mg/l) Tingkat Kesuburan 0-0,002 Kurang subur 0,0021-0,050 Cukup subur 0,051 - 0,100 Subur 0,101-0,200 Sangat subur $>0,201$ Sangat subur sekali Hal ini bahwa Muara Sungai Bodri memiliki kandungan fosfat tinggi dan merupakan perairan yang subur.

Pola persebaran kandungan fosfat pada 3 perioda sampling di muara Sungai Bodri menunjukkan pola yang berbeda. Secara keseluruhan pola persebaran kandungan fosfat berkaitan erat dengan arah arus. Pada perioda sampling 30 Juni 2018 menunjukkan pola persebaran kandungan fosfat berbentuk konvergen persebaran pertama pada stasiun 1, 2, 5 dan 7 serta persebaran kedua pada stasiun 6, 8 dan 9, dengan arah arus dari Tenggara berbelok ke Barat (Gambar 8). Persebaran kandungan fosfat pada perioda sampling tanggal 1 
September 2018 berbentuk konvergen sejalan dengan garis pantai, dimana lapisan pertama, lapisan yang dimaksud adalah persebaran fosfat disusun oleh stasiun 1, 2 dan 3 ; sedangkan pada lapisan kedua tersusun oleh stasiun 5, 6 dan 7 ; serta pada lapisan ketiga tersusun oleh stasiun 7, 8 dan 9. Sedangkan arah arus berasal dari arah Barat Daya menuju ke Tenggara (Gambar 9). Selanjutnya pada sampling tanggal 27 Oktober 2018, persebaran kandungan fosfat berbentuk konvergen. Lapisan berikutnya disusun oleh stasiun 3, 2, 4 dan 9; serta lapisan terluar tersusun oleh stasiun 1,7 dan 8. Arah arus berasal dri Tenggara menuju Barat Daya (Gambar 10). Domingues et. al. ( 2011), Kramer (2014), dan Cira et. al. (2016) menjelaskan bahwa sistem percampuran yang terjadi pada lapisan perairan maupun badan air yang diakibatkan oleh arus, yang dapat terjadi secara interaktif terjadi secara simultan.

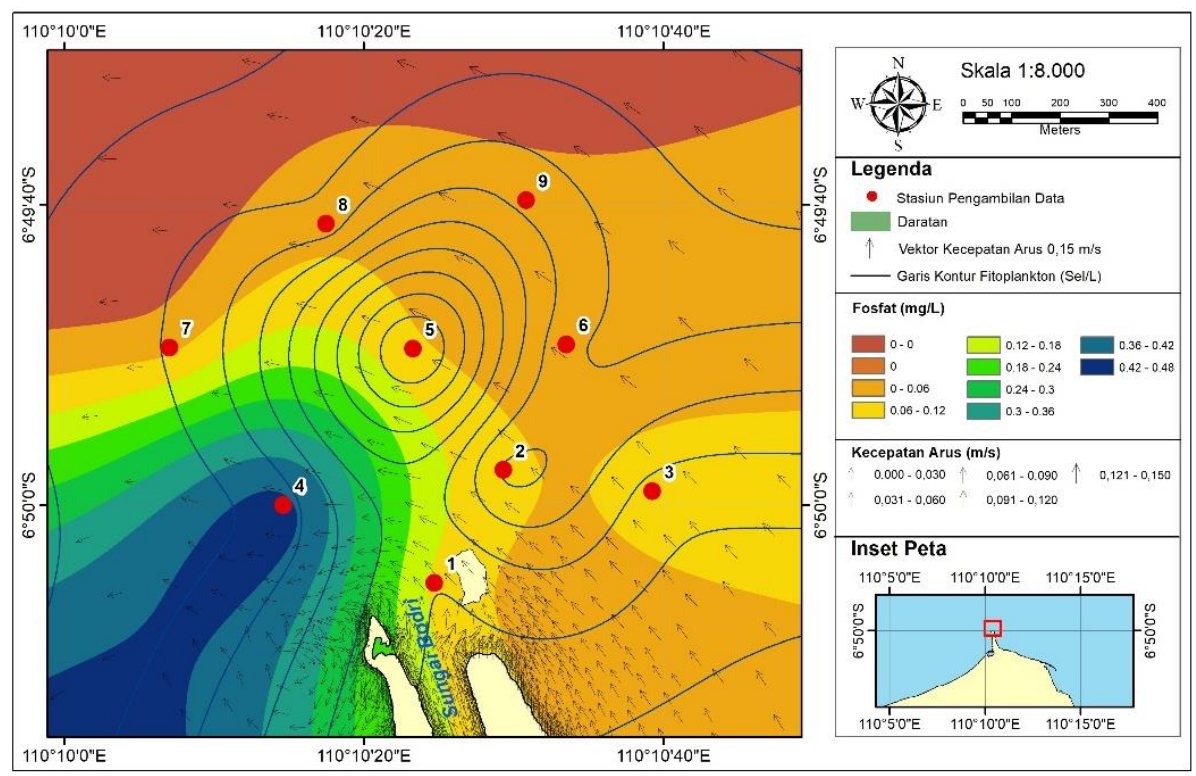

Gambar 7. Overlay antara fitoplankton, fosfat, dan pola arus tanggal 30 Juni 2018 di Muara Sungai Bodri, Kendal

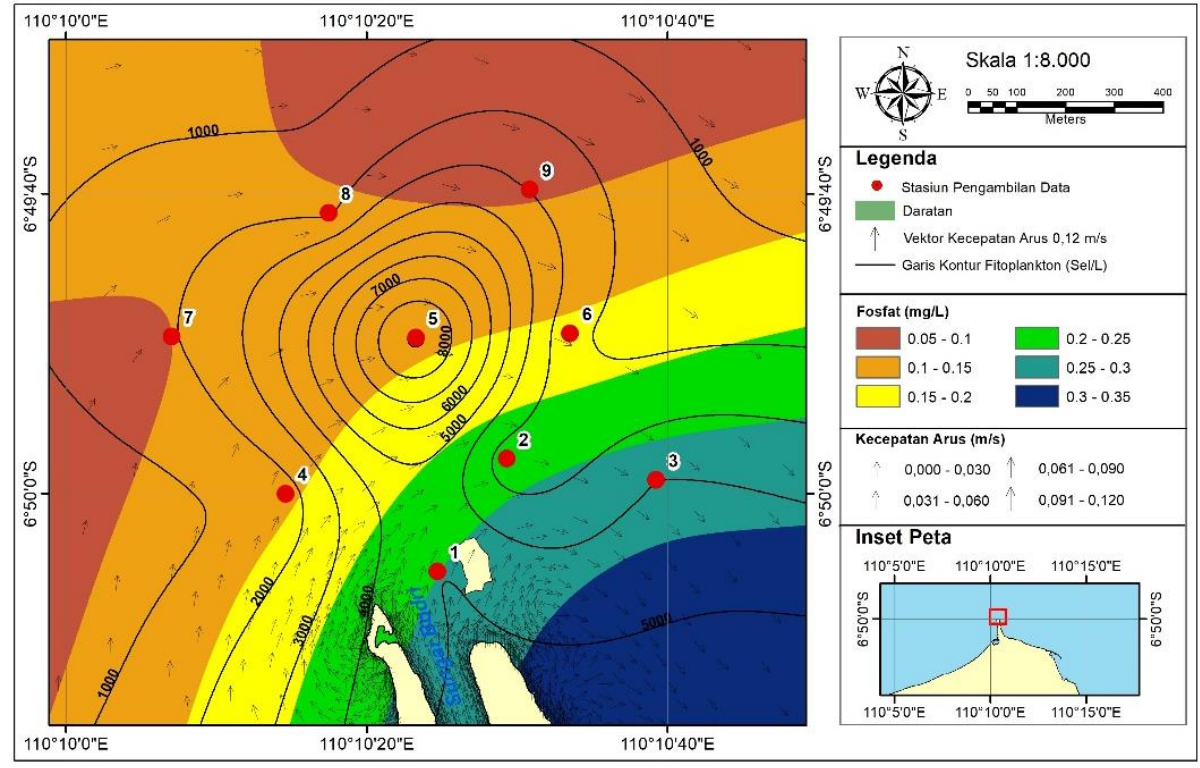

Gambar 8. Overlay antara fitoplankton, fosfat, dan pola arus tanggal 1 September 2018 di Muara Sungai Bodri, Kendal 


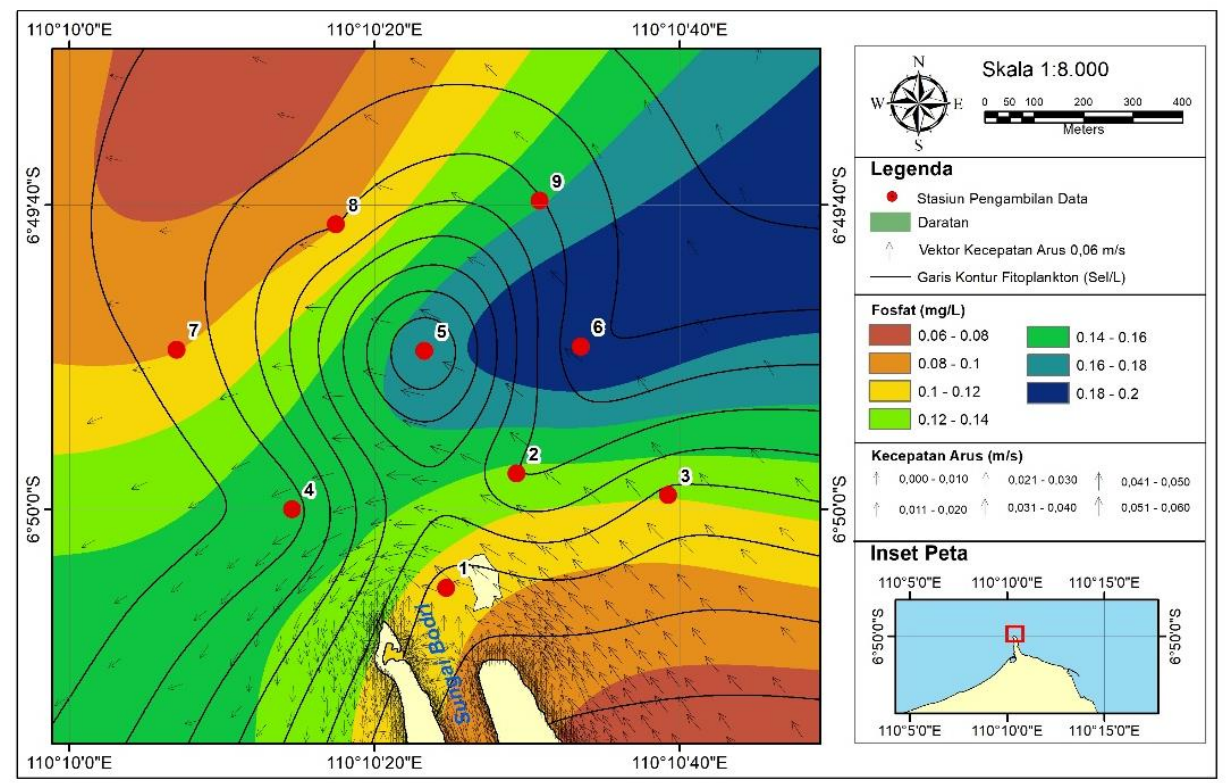

Gambar 9. Overlay antara fitoplankton, fosfat, dan pola arus tanggal 27 Oktober 2018 di Muara Sungai Bodri, Kendal

Selanjutnya ditambahkan bahwa sumber fosfat di perairan laut pada wilayah pesisir dan paparan benua adalah sungai. Aliran air di sungai akan membawa hanyutan sampah maupun sumber fosfat daratan sehingga sumber fosfat di muara sungai lebih besar dari sekitarnya. Keberadaan fosfat di dalam air akan terurai menjadi senyawa ionisasi antara lain dalam bentuk ion $\mathrm{H}_{2} \mathrm{PO}_{4^{-}}$, $\mathrm{HPO}_{4}^{2-}, \mathrm{PO}_{4}^{3-}$. Fosfat akan diabsorpsi oleh fitoplankton dan seterusnya masuk ke dalam rantai makanan. Sumber antropogenik fosfor adalah dari limbah industri dan limbah domestic (Damar et al., 2020). Persebaran kandungan fosfat berdasarkan Maslukah, et al., (2019) menyatakan bahwa keberadaan fosfat di dalam air akan terurai menjadi senyawa ionisasi bahwa ion - ion tersebut akan dengan mudah mengikuti kondisi lingkungan dipengaruhi oleh faktor fisika oseanografi yang kuat. Persebaran kandungan fosfat di muara Sungai Kali Bodri terkait erat dengan faktor arus dan pasang surut, yang memberikan pola persebaran sesuai dengan kondisi lingkungan.

Analisis tumpang susun kandungan fosfat dengan kelimpahan plankton menunjukkan bahwa garis tengah / titik sumbu tetap terjadi pada stasiun 4, 5 dan 6, dipengaruhi arus. Hal ini menunjukkan bahwa persebaran kandungan fosfat akan dimanfaatkan oleh fitoplankton sesuai perkembangan dan siklus hidupnya. Fosfat adalah unsur esensial sebagai bahan nutrien bagi berbagai biota akuatik (Wisha et al., 2018).

\section{KESIMPULAN}

Berdasarkan hasil penelitian ini dapat disimpulkan bahwa perairan Muara Sungai Bodri, Kabupaten Kendal dalam kondisi subur / eutrofik. Pola sebaran Nitrat (N) terhadap jenis dan kelimpahan fitoplankton di Perairan Muara Sungai Bodri, Kendal berbentuk konvergen pada stasiun di bagian barat, serta searah dengan garis pantai pada stasiun di bagian timur. Sedangkan pola sebaran Fosfat (P) terhadap jenis dan kelimpahan fitoplankton di Perairan Muara Sungai Bodri, Kendal mempunyai pola yang berbeda berdasarkan tanggal sampling, dengan persebaran yang dipengaruhi oleh arus dari Tenggara ke Barat Daya pada perioda Juni dan Oktober 2018, serta dari Barat Daya ke Tenggara pada perioda September 2018. Selanjutnya ideks kesuburan Perairan Muara Sungai Bodri, Kabupaten Kendal menunjukkan tingkat kesuburan yang tinggi atau eutrofik dengan nilai keanekaragaman dan keseragaman yang tinggi, serta nilai dominansi yang rendah.

\section{DAFTAR PUSTAKA}

Mayagitha, K.A., Haeruddin, \& Rudiyanti, S. 2014. Status Kualitas Perairan Sungai Bremi Kabupaten Pekalongan Ditinjau Dari Konsentrasi TS, BOD, COD, dan Struktur Komunitas Fitoplankton. Diponegoro Journal of Marquares, 3(1):177-185.

Agustiningsih, D., Sasongko, S.B. \& Sudarno, 2012. Analisis Kualitas Air dan Beban 
Pencemaran Berdasarkan Penggunaan Lahan di Sungai Blukar Kabupaten Kendal. Prosiding Seminar Nasional Pengelolaan Sumberdaya Alam dan Lingkungan, Semarang, 11 September 2012. Hal 30-37.

Barus, T.A. 2004. Pengantar Limnologi Studi Tentang Ekosistem Sungai dan Danau. Medan: Fakultas MIPA USU. 65hal

Cahyanti, Dwi, S., Endrawati, H. \& Supriyantini, E. 2014. Struktur Komunitas Fitoplankton pada Daerah Pertambakan di Desa Mangunharjo Kecamatan Tugu Kota Semarang. Journal of Marine Research, 3(4): 527-534.

Cermeño, P., Chouciño, P., Fernández-Castro, B. \& Vallina, S.M. 2016. Marine Primary Productivity Is Driven by a Selection Effect. Frontiers in Marine Science 3:173. doi: 10.3389/fmars.2016.00173. CC BY 4.0. 19p.

Damar, A., Colijn, F., Hesse, K.J. \& Kurniawan, F. 2020. Coastal Phytoplankton Pigments Composition in Three Tropical Estuaries of Indonesia. Journal of Marine Science and Enggineering, 8(311):1-20.

Dewi, R., Zainuri, M., Anggoro, S., Winanto, T. \& Endrawati, H. 2017. Characteristic and The Distribution of Spatio-Temporel Macronutrient in the Lagoon Area of Segara Anakan. International Journal of Marine and Aquatic Resource Conservation and Coexistence. 2(1):51-57

Diposaptono, S., Budiman \& Agung, F. 2009. Menyiasati Perubahan Iklim di Wilayah Pesisir dan Pulau-pulau Kecil. PB Sarana Komunikasi Utama, Bogor. 242 hal.

Diposaptono, S., 2015. Strategi Adaptasi dan Mitigasi akibat Perubahan Iklim di Wilayah Pesisir dan Pulau-pulau Kecil. Modul Pelatihan Perencanaan Tata Ruang di Wilayah Pesisir. Hal : 1-28

Domingues, R.B., Barbosa, A.B., Sommer, U. \& Galvão, H.M. 2011. Ammonium, nitrate and phytoplankton interactions in a freshwater tidal estuarine zone: potential effects of cultura eutrophication. Aquatic Science, 73:331-343.doi:10.1007/s00027-011-0180-0.

Cira, E.K., Paerl, H.W. \& Wetz, M.S. 2016. Effects of nitrogen availability and form on phytoplankton growth in a eutrophied estuary (Neuse River Estuary, NC, USA). PloS one, 11(8):e0160663. doi: 10.1371/journal.pone. 0160663. 15p
Erickson III, D.J., Sulzberger, B., Zepp, R.G., \& Austin, A.T. 2015. Effects of stratospheric ozone depletion, solar UV radiation, and climate change on biogeochemical cycling: interactions and feedbacks. Photochemical \& Photobiological Sciences, 14:127-148. doi: 10.1039/c4pp90036g

Fachrul, F.M., Haeruman, H. \& Sitepu, L.C. 2005. Komunitas fitoplankton sebagai bio-indikator kualitas perairan Teluk Jakarta. Seminar Nasional MIPA 2005.FMIPA-Universitas Indonesia, 24-26 November 2005, Jakarta. 11 hal.

Falkowski., P.G., 2003. Biogeochemistry of Primary Production in the Sea. Rutgers University, New Brunswick, NJ, USA. Elsevier Ltd. 8:185-213

Gemilang, W.A., Wisha, U.J., Rahmawan, G.A. \& Dhiauddin, R. 2018. Karakteristik Sebaran Sedimen Pantai Utara Jawa : Studi Kasus Kecamatan Brebes, Jawa Tengah. Jurnal Kelautan Nasional, 13(2):65-74.

Hutabarat, P. U. B., Redjeki, S., \& Hartati, R. 2014. Komposisi Dan Kelimpahan Plankton Di Perairan Kayome Kepulauan Togean Sulawesi Tengah. Journal of Marine Research, 3(4):447-455.

Indriany, M. 2005. Struktur Komunitas Diatom dan Dinoflagellata pada Beberapa Daerah Budidaya di Teluk Hurun, Lampung. Program Studi Biologi Universitas Negeri Jakarta. Jakarta. $125 \mathrm{hlm}$.

Iswanto, C. Y., Hutabarat, S., \& Purnomo, P. W. 2015. Analisis Kesuburan Perairan Berdasarkan Keanekaragaman Plankton, Nitrat dan Fosfat di Sungai Jali dan Sungai Lereng Desa Keburuhan, Purworejo. Journal of Management of Aquatic Resources, 4(3):84-90.

Jones-Lee, A., \& Lee, G.F. 2005. Eutrophication (Excessive Fertilization). Water Encyclopedia: Surface and Agricultural Water. Wiley, Hoboken, NJ.p 107-114.

Kramer, S. 2014. The Relationship between Nitrate Concentration and Phytoplankton Blooms in Harpswell Sound. Bowdoin College, Marine Lab Student Papers and Projects. Student Scholarship and Creative Work. 11p.

Kurniawan, Purwiyanto, A.I.S. \& Fauziyah. 2016. Hubungan nitrat, fosfat dan ammonium terhadap keberadaan makrozoobenthos di Perairan Sungai Lumpur, Kabupaten Ogan 
Komering Ilir, Sumatera Selatan. Maspari Journal, 8(2):101-110.

Kusumaningtyas, D. I. (2016). Analisis Kadar Nitrat dan Klasifikasi Tingkat Kesuburan di Perairan Waduk Ir. H. Djuanda, Jatiluhur, Purwakarta. Buletin Teknik Litkayasa Sumber Daya dan Penangkapan, 8(2):49-54.

Linus, Y., Salwiyah, dan Irawati, N. 2016. Status Kesuburan Perairan berdasarkan Kandungan Klorofil-a di Perairan Bungkutoko Kota Kendari. Jurnal Manajemen Sumber Daya Perairan, 2(1):101-111.

Maslukah, L., Wulandari, S.Y., Prasetyawan, I.B. \& Zainuri, M., 2019. Distributions and Fluxes of Nitrogen and Phosphorus Nutrients in Porewater Sediments in the Estuary of Jepara. Journal of Ecological Engineering. 20(2):110.

Muhaemin, M., Practica, F., \& Agustina, T. 2014. Starvasi Nitrogen dan Pengaruhnya terhadap Biomassa dan Protein Total Nannochloropsis sp. Maspari Journal, 6 (2) : 98-103.

Odum, E.P. 1994. Dasar-dasar Ekologi, edisi ketiga. [Terjemahan dari Fundamentals of ecology, third edition]. Samingan $\mathrm{T}$ (penerjemah). Gajah Mada University Press. Yogyakarta. $696 \mathrm{hlm}$.

Panagiotaras, D., Koulougliotis, D., Nikolopoulos D., Kalarakis, A.N., Yiannopoulos, A.Ch. \& Pikios, K. 2015. Biogeochemical Cycling of Nutrients and Thermodynamic Aspects. Journal of Thermodynamics \& Catalysis. 6(2):1-7. doi: 10.4172/2157-7544.1000144

Patricia, C., Astono, W. \& Hendrawan. D.I. 2018. Kandungan Nitrat dan Fosfat di Sungai Ciliwung. Seminar Nasional Cendekiawan ke 4 Tahun 2018.

Patty, S.I. 2014. Karakteristik Fosfat, Nitrat Dan Oksigen Terlarut di Perairan Pulau Gangga dan Pulau Siladen, Sulawesi Utara. Jurnal Ilmiah Platax, 2(2):74-84.

Patty, S.I., Arfah, H. \& Abdul, M.S. 2015. Zat Hara (Fosfat, Nitrat), Oksigen Terlarut dan $\mathrm{pH}$ Kaitannya dengan Kesuburan di Perairan Jikumerasa, Pulau Buru. Jurnal Pesisir dan Laut Tropis, 3(1):43-50.

Portal Resmi Kabupaten Kendal, 2020. kendalkab.go.id. Upload 15 Juni 2020.

Ramanda, O.A., Sulardiono, B. \& Ain, C. 2018.
Analisa Kualitas Perairan Ditinjau Dari Tingkat Saprobitas Dan Kandungan Klorofil Di Muara Sungai Bodri Kendal. Management of Aquatic Resources Journal, 6(1):67-76.

Risamasu, F.J.L \& Prayitno, H.B. 2011. Kajian Zat Hara Fosfat, Nitrit, Nitrat dan Silikat di Perairan Kepulauan Matasiri, Kalimantan Selatan. Ilmu Kelautan. 16(3):135-142.

Sastrawijaya, T. 2009. Pencemaran Lingkungan. PT. Rineka Cipta. Jakarta. 165hal.

Sidaningrat, I.G.A.N., Arthana, I.W., \& Suryaningtyas, E.W. 2018. Tingkat Kesuburan Perairan Berdasarkan Kelimpahan Fitoplankton di Danau Batur, Kintamani, Bali. Jurnal Metamorfosa, 5(1):79-84.

Soegiarto, A., 1976. Pedoman Umum Pengelolaan Wilayah Pesisir. Lembaga Oseanologi Nasional. Jakarta. 80p.

Tuwo, A., 2011. Pengelolaan Ekowisata Pesisir dan Laut. Pendekatan Ekologi, SosialEkonomi, Kelembagaan dan Sarana Wilayah. Penerbit Brilian International. 234hal.

Utami, T.M.R., Maslukah, L. \& Yusuf, M. Sebaran Nitrat (NO3) dan Fosfat (PO4) Di Perairan Karangsong Kabupaten Indramayu. Buletin Oseanografi Marina, 5(1):31-37

Welch, P.S., 1952. Lymnologycal Methods. Mc. Graw-Hill Book Company Ltd. New York, $381 \mathrm{pp}$.

Widada, S. 2015. Geologi Wilayah Pesisir. Modul Pelatihan Perencanaan Tata Ruang di Wilayah Pesisir. Hal : 29-61.Yogyakarta. Kanisius. 111hal.

Wisha, U.J., Ondara, K. \& Ilham. 2018. The Influence of Nutrient ( $\mathrm{N}$ and $\mathrm{P}$ ) Enrichment and Ratios on Phytoplankton Abundance in Keunekai Waters, Weh Island, Indonesia. Makara Journal of Science, 22(4):187-197.

Yuliana., Adiwilaga, M.E., Harris, E., \& Pratiwi, N.T.M. 2012. Hubungan Antara Kelimpahan Fitoplankton dengan Parameter FisikKimiawi Perairan di Teluk Jakarta. Jurnal Antartika, 3(2):169-179.

Zainuri, M., 2010. Kontribusi Sumberdaya Fitoplankton terhadap Produktivitas dan Keseimbangan Ekosistem dalam Pengelolaan Wilayah Pesisir. Pidato Pengukuhan Guru Besar. Undip Press. 78 hal. 